\title{
Corporate Equality and Equity Prices: Doing Well While Doing Good?
}

Shihe Fu and Liwei Shan

\section{EERI Research Paper Series No 09/2009}

ISSN: 2031-4892

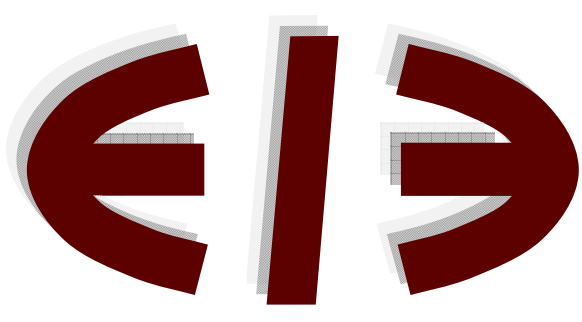

\section{EERI}

Economics and Econometrics Research Institute Avenue de Beaulieu 1160 Brussels

Belgium

Tel: +3222993523

Fax: +322 2993523

www.eeri.eu 


\title{
Corporate Equality and Equity Prices: Doing Well While Doing Good?
}

\author{
Shihe Fu \\ and \\ Liwei Shan
}

March 12, 2009

\begin{abstract}
Two competing hypotheses, value enhancing and value discounting, state that implementing socially responsible corporate policies can have positive or negative effects on firm value. This paper tests how a specific type of social responsibility-corporate equality-affects firm value. Corporate equality is measured by the corporate equality index (CEI). This index quantifies how companies treat their gay, lesbian, bisexual, and transgender employees, consumers, and investors. Using a sample of CEI-rated, publicly traded firms in the U.S., we find that, between 2002 and 2006, firms with a higher degree of corporate equality have higher stock returns and higher market valuation $(\mathrm{Q})$. We provide suggestive, causal evidence that corporate equality enhances firm value through better performance in product markets and labor markets: Firms with a higher degree of corporate equality also tend to have larger sales, higher profit margins, higher employee productivity, and attract more employees. These results are robust to the inclusion of unobserved firm-heterogeneities. Overall, our results support the value-enhancing effects of corporate social responsibility.
\end{abstract}

JEL Classification: G11; G12; J70; M14

Keywords: Corporate equality; social responsibility; socially responsible investment; stock returns; performance

Shihe Fu and Liwei Shan are from the Research Institute of Economics and Management, Southwestern University of Finance and Economics, Chengdu, China. We thank Richard Arnott, Zhihong Chen, Philip Dybvig, Li Gan, Ying Ge, Han Li, Jun Liu, Judy Pereira, and seminar participants at Southwestern University of Finance and Economics and University of International Business and Economics for helpful comments and Tao Zheng for research assistance. Corresponding author, Liwei Shan. Email: Lshan@swufe.edu.cn. Phone: 86-28-8709-9204. 


\section{Introduction}

The growing literature on corporate social responsibility has provided mixed results on how social responsibility affects firm value. This paper contributes to the social responsibility literature by testing how and through what channels firm value is affected by a specific type of social responsibility-corporate equality. Corporate equality is measured by the corporate equality index (CEI). This index quantifies how companies treat their gay, lesbian, bisexual, and transgender (GLBT) employees, consumers, and investors.

In the literature, a socially responsible company is defined based on a broad set of different criteria, including ethical, social, and environmental criteria. For example, a company is considered socially irresponsible if it is involved in producing alcohol, tobacco, and gambling, or has operations in South Africa, or is engaged in military weapons or nuclear power. In contrast, a company is considered socially responsible if it contributes to pollution reduction, has good employee relations or good corporate governance, or has significant participation in the community.

As more and more firms have implemented socially responsible policies, a natural question arises: Does social responsibility affect firm value? Most of the existing evidence comes from studies testing the excess returns of socially responsible investments (SRI). Compared to conventional portfolios, SRI portfolios can have better or poorer performance, which we call the value-enhancing hypothesis and value-discounting hypothesis, respectively. Proponents of the value-discounting hypothesis argue that SRI portfolios cannot outperform conventional portfolios because using a set of SRI criteria to screen securities imposes a constraint on the choice set of risk-return optimization, resulting in reduced diversification. In addition, investors who care about social responsibility may derive non-financial utility from SRI by holding assets consistent with SRI screening criteria, or are willing to pay a price to avoid holding unethical assets; therefore, they would accept a lower rate of return.

Many studies have provided supportive evidence for the value-discounting hypothesis. Hamilton, Jo, and Statman (1993), Mallin, Saadouni, and Briston (1995), Sauer (1997), Goldreyer and Diltz (1999), Statman (2000), Bello (2005), and Bauer, Koedijk, and Otten (2005) all find that the performance of socially responsible mutual funds is not statistically different from the performance of conventional mutual funds. Hong and Kacperczyk (2009) find that sin stocks (publicly traded companies involved in producing alcohol, tobacco, and gambling) outperform other comparable stocks. They argue that sin stocks are underpriced because they are neglected by an important set of investors, and that greater litigation risk is associated with sin stock companies, further increasing the expected returns of sin stocks. Since SRI is the opposite of sin stocks, SRI should have lower returns than comparables. Geczy, Stambaugh, and Levin (2005) find that SRI constraints impose substantial costs on investors. More compelling results are found in Renneboog, Horst, and Zhang (2008). They use an international data set and find that the average socially responsible funds in the U.S., the U.K., and many European and Asian countries underperform their domestic conventional

\footnotetext{
${ }^{1}$ Renneboog, Horst, and Zhang (2008) summarize 21types of social responsibility screening criteria. Statman (2006) reviews four types of socially responsible indexes.
} 
funds by $-2.2 \%$ to $-6.5 \%$ per year, and the results are robust even after controlling for screening activities and major fund characteristics such as size, age, and management fees.

In contrast, the value-enhancing hypothesis states that SRI portfolios can outperform conventional counterparts due to the following reasons. First, socially responsible corporate policies increase firm value by better protecting shareholders. For example, Gompers, Ishii, and Metrick (2003) construct a corporate governance index to measure the degree of shareholder protection, and they find that firms with stronger shareholder rights have higher abnormal returns. Second, if socially responsible corporate policies are considered of value to consumers and employees, sales will increase and employee relations will improve, which can translate into a higher firm value. Heal (2005) provides a few examples and demonstrates that consumers value social responsibility and are motivated to buy socially responsible products and services. This "brand equity" effect will increase sales of socially responsible companies. He also argues that companies with good employee relations can attract and retain good employees. Employee loyalty helps improve productivity and innovation, thus enhancing profitability. Finally, socially responsible criteria adopted by a company may result in cost savings, implicit or explicit, thus increasing the firm's value. For example, Heal (2005) argues that implementing socially responsible corporate policies can reduce potential conflicts between companies and society, which generates net cost savings.

A few recent empirical studies support the value-enhancing hypothesis. Statman (2007) finds that a socially responsible portfolio can have better performance. Kempf and Osthoff (2007) use the KLD Research \& Analytics, Inc. rating data to form a portfolio of stocks with high SRI ratings and another with low SRI ratings. ${ }^{2}$ A long-short trading strategy (long in the high-rated stocks and short in the low-rated stocks) can generate abnormal returns, up to $8.7 \%$ per year. Both studies conclude that companies doing "good" can also do well, suggesting that capital markets do value social responsibilities. ${ }^{3}$

In this paper, we focus on a specific type of social responsibility-corporate equality, measured by the corporate equality index (CEI). This index quantifies how large U.S. businesses treat their GLBT employees, consumers, and investors. Although corporate equality can be measured by other indexes, such as policies preventing employment discrimination against women, minority, or disabled people, such policies are legalized nationally. However, non-discrimination policies based on sexual orientation vary tremendously across states, cities, and firms. Such variation across firms is ideal for the purpose of this study.

Like people valuing democracy, peace, environment quality, and such, people also value corporate equality, from different perspectives. As a specific type of social responsibility, does corporate equality have any real impact on firm value? So far, there has been no empirical study identifying the effect of corporate equality, although value-discounting and

\footnotetext{
${ }^{2}$ The KLD rating is based on a set of comprehensive indicators, including environmental, social, and corporate governance, among which the policies towards gays and lesbians are considered. For details of the KLD ratings indicators, please visit www.kld.com/research/stats/indicators.html.

${ }^{3}$ In a meta-analysis of 167 studies on the relationship between corporate social performance and corporate financial performance from 1972 to 2007, Margolis, Elfenbein, and Walsh (2007) conclude that, overall, such a relationship is mildly positive.
} 
value-enhancing hypotheses make opposite predictions of its effect on firm value. We use the CEI scores published by the Human Rights Campaign Foundation (HRC) from 2002 to 2006, to examine how corporate equality affects firm value. Consistent with the valueenhancing explanation, our results indicate that firms with a higher level of corporate equality have higher stock returns and higher market valuation (Q). We also find supportive, causal evidence that corporate equality affects firm value through two channels-product markets and labor markets: Firms with higher CEI scores have more sales, higher profit margins, higher productivity in terms of total revenue per employee, and attract more employees. Our results suggest that corporate equality is appreciated by both consumers and employees, which can translate into higher firm value through better performance in product markets and labor markets. We further examine what determines the CEI score, and we find that firms that are younger, larger, have higher R\&D expenses, and have higher leverage, tend to achieve higher CEI scores. Our results suggest that firms have a higher level of corporate equality possibly because of the need to attract talent, or to keep a good public image.

Our study contributes to the literature in several ways. First, we contribute to the growing literature on social responsibility by studying a special type of social responsibilitycorporate equality. ${ }^{4}$ Second, we contribute to the SRI literature through the analysis of the effect of corporate equality on stock returns. We find evidence consistent with the valueenchaning explanation that socially responsible corporate policies enhance firm value. Third, we provide suggestive, causal evidence from product markets and labor markets, to identify the mechanisms through which corporate equality affects firm value. Finally, we analyze the determinants of corporate equality, which is one of the few studies that empirically identify the determinants of socially responsible corporate policies. Our study also provides empirical evidence of the effectiveness of advocacy of corporate equality. Advocates of corporate equality, such as the HRC, have found that more and more people become aware of corporate equality issues and support more socially responsible, more equal companies. However, there is literally no empirical analysis on the effectiveness of the advocacy of corporate equality.

The next section introduces the data sets. Section 3 presents our hypotheses, testing methodology, and empirical results, from the perspectives of capital markets, product markets, and labor markets. Section 4 tests what firm and industrial characteristics affect the CEI score, and section 5 concludes.

\section{Data}

Our data come from three sources. Our measure of corporate equality-corporate equality index (CEI) -is collected manually from the annual report Corporate Equality Index from 2002 to 2006, available from the HRC web site (www.hrc.org). In 2002, the HRC, the largest national gay, lesbian, bisexual and transgender (GLBT) civil rights organization in the U.S., began conducting an annual survey to rate large U.S. businesses on how they treat their GLBT employees, consumers, and investors, and initiated publication of an annual

\footnotetext{
${ }^{4}$ Lev, Petrovits, and Radhakrishnan (2006) study how another specific type of social responsibility-corporate charitable contributions-affect revenue growth.
} 
report on CEI. The CEI rates a company on a scale between 0 and 100 with 100 being the highest equality. ${ }^{5}$ Companies achieving a full score of 100 are selected as "the best places to work" in the annual "The State of Workplace," a report that collects information on laws and policies concerning sexual orientation and gender identity in the workplace across the U.S., and aims to promote workplace diversity. Consumer-orientated businesses are included in the annual "Buying for Equality," a guide advising consumers to buy products and services from companies with higher CEI scores.

The 2002 sample that the HRC surveyed includes Fortune magazine's 500 largest publicly traded companies in 2002, and 200 of the largest privately owned companies from the 2001 Forbes magazine's Private 500, and other companies that the HRC had sufficient information to rate. The sample expands over time to include the Fortune 1000, the Standard \& Poor's 500, Forbes' list of the 200 largest privately held firms, and the American Lawyer 100 in 2006. There are a total of 1,908 firm-year observations from 2002 to 2006. For our research purposes, we restrict our sample to the companies that are publicly traded and are included in both the CRSP and Compustat databases.

We obtain monthly stock return data from the Center for Research in Security Prices (CRSP) and financial statement variables from Compustat. In order to link the CEI data with the CRSP and Compustat data sets, we first match the CEI data with the Compustat data by company name, through a company-name-matching algorithm as described in Kerr and Fu (2008). This combined data set is further merged with the CRSP data through the CRSP and Compustat merged file obtained from Wharton Research Data Services. To ensure accuracy, we also check manually both matched and unmatched firms. The final data set contains 1,283 firm-year observations in both CRSP and Compustat from 2002 to 2006.

Table 1 presents summary statistics for our sample. Panel A presents descriptive statistics of CEI by year. In general, the CEI scores increase from 2002 to 2006. The average CEI score is 71.3 and the median is 75. Panel B presents summary statistics of the variables used in this paper. Following the prior literature, $Q$ is defined as the ratio of the market value of assets to the book value of assets (data6), where the market value is the book value of assets plus the market value of common stock (data25*data199) less the book value of common stock (data60+data74). Age is the number of years that a firm is available in CRSP. $\log ($ Sales $)$ is the natural logarithm of sales (data12). $\log ($ Employee) is the natural logarithm of the number of employees in million (data29). Herfindahl index is the sum of squared salesbased market shares of all firms in Compustat in a 2-digit SIC industry in a given year and its value lies between 0 and $1 . \log (B M)$ is the logarithm of the ratio of book value of equity to the market value of equity. Net profit margin is income before extraordinary items (data18) divided by sales. Leverage is the ratio of total debt (data6-book value of equity) divided by the market value of total assets. $S \& P 500$ Firm is a dummy set to one if a firm is included in the S\&P 500 index and zero otherwise. $R O E$ is net income (data172) to the book value of

\footnotetext{
${ }^{5}$ The rating indicators include whether a company includes "sexual orientation" and "gender identity" in its equal employment opportunity policy and whether a company provides diversity training on sexual orientation and gender identity, or the company has supportive gender transition guidelines, domestic partner health insurance, and at least one transgender wellness benefit. For details, see the survey questionnaire of each CEI report, available at http://www.hrc.org/issues/ceihome.asp.
} 
equity. Following Hong and Kacperczyk (2009), Sin is a dummy set to one if a firm belongs to alcohol, tobacco or gambling industries. ${ }^{6}$ In our sample, there are only 33 firm-year observations for a total of eight unique firms in sin industries. $Q$, Size, $\log (\operatorname{Sales}), \log (B M)$, Herfindal index, Leverage, ROE, Log(employee), and Net profit margin are winsorized at the $1 \%$ and $99 \%$ levels.

We examine the effect of corporate equality on contemporaneous stock returns, as well as on future stock returns. Therefore, we use five different methods to form portfolios, in order to allow for different length of lags between CEI and stock returns. The baseline method is matching year t CEI with monthly stock returns from January of year $t$ to December of year $t$. Since new CEI data are usually released in August or September of each year, we follow Gompers, Ishii, and Metrick (2003) to allow a one-month delay for investors to react to the new CEI information. Therefore, our second portfolio formation is matching year $t$ CEI with monthly stock returns from October of year $t$ to September of year $t+1$. The third portfolio formation is matching year $t$ CEI with monthly stock returns from January of year $t+1$ to December of year $t+1$. The fourth portfolio formation follows the asset pricing tests by Fama and French $(1992,1993)$. We match CEI in year t with monthly stock returns from July of year $t+1$ to June of year $t+2$. Lastly, we form portfolios for an extreme situation where investors use the first year CEI available to form portfolios, and then they do not react to updated CEI information in the following years. Although this situation is most unlikely, we still form portfolios accordingly for the sake of robustness. In this case, we match the first year CEI of each stock with the monthly returns in each year except the first year. Since the baseline portfolio formation examined CEI and contemporaneous stock returns, we skip the first-year stock returns, to avoid results driven by the same factor as captured by the baseline portfolio formation. This skipping procedure actually biases our results towards insignificance, if our results are driven by the contemporaneous correlation between CEI and stock returns. $^{7}$

Each year, we sort CEI scores into quartiles, and form monthly quartile portfolios using the five formation methods discussed above. Portfolios are rebalanced separately at each time point, according to the five formation methods. In Table 2, we report the average equallyweighted monthly quartile portfolio returns for each formation method, with t-statistics calculated using Newey-West standard errors. In general, for all of the five formation methods, portfolio returns increase as CEI increases from the lowest quartile to the highest quartile. Moreover, the difference between returns of the highest quartile and the lowest quartile is significantly positive in all cases.

\section{Empirical tests}

\subsection{Does corporate equality affect firm value?}

\footnotetext{
${ }^{6}$ Sin industries include SIC2100-2199, SIC 2080-2085, NAICS 7132, 71312, 713210, 71329,713290, 72112, and 721120 .

${ }^{7}$ For robustness checks, we re-do all tests without skipping the first year, and find that most results are much stronger (the results are not reported in this paper but are available upon request).
} 
Hong and Kacperczyk (2009) and Renneboog, Horst and Zhang (2008) argue that investors valuing social responsibility are constrained in their investment sets, leading to lower returns. Socially responsible investors may also be willing to accept lower financial returns since they may derive non-financial utility from investing in assets consistent with their social norms. This value-discounting hypothesis predicts that firms with a higher CEI score have lower returns. In contrast, Gompers, Ishii, and Metrick (2003) point out that more democratic governance enhances firm value and leads to higher stock returns, suggesting that firms caring more about social responsibility will ultimately create more value for shareholders. This value-enhancing explanation predicts that firms with a higher CEI score have higher returns.

To test these two competing hypotheses, we follow Hou and Robinson (2006) and Hong and Kacperczyk (2009), to perform a firm-level test using monthly returns. Following the standard procedure, accounting data in year $t$ are matched with stock returns from July of year $\mathrm{t}+1$ to June of year $\mathrm{t}+2$. The model is specified as follows:

$$
\begin{aligned}
R_{i t}= & \alpha+\beta_{1} C E I_{i t}+\beta_{2} \log (\text { Size })_{i t}+\beta_{3} \log (B M)_{i t}+\beta_{4} \text { Momentum }_{i t} \\
& +\beta_{5} \text { Beta }_{i t}+\beta_{6} \text { Leverage }_{i t}+\varepsilon_{i t}
\end{aligned}
$$

where $i$ stands for firm and $t$ for month. The dependent variable is the monthly stock returns in percentage points. Size is the market value of equity in June of year $\mathrm{t}+1$. Momentum is the previous twelve months' returns. Beta is the market model beta estimated using the prior 36 monthly value-weighted CRSP index returns. $\log (B M)$ and Leverage are as defined in Table 1. Following Fama and MacBeth (1973), we run cross-sectional regressions every month and report the time-series average values of the monthly regression coefficients with time-series t-statistics calculated using Newey-West standard errors. Results are summarized in Table 3.

Consistent with the value-enhancing explanation, the coefficient of CEI is positive and statistically significant-at least at the $10 \%$ level-in all model specifications. After controlling for firm characteristics, an increase in CEI score by ten points is associated with a higher return of between 0.37 to 0.66 percentage points per year.

Next, we follow Fama and French (1993), Carhart (1997), and Gompers, Ishii, and Metrick (2003)'s methodology to perform a portfolio test. As in Table 2, we sort CEI each year into quartiles, and calculate equally-weighted monthly returns for each quartile. We specify a four-factor model to test monthly portfolio returns for the 60 months period between January 2002 and December 2006:

$$
R_{t}-R_{f}=\alpha+\beta_{1}(R M-R F)_{t}+\beta_{2} S M B_{t}+\beta_{3} H M L_{t}+\beta_{4} \text { Momentum }_{t}+\varepsilon_{t},
$$

where the dependent variable is the equally-weighted monthly portfolio returns, $R_{t}$, minus the risk-free rate $R_{f}$ in percentage points. $R M-R F$ is the monthly market returns in excess of the risk-free rate. SMB, HML and Momentum are risk factors defined in Fama and French (1993) and Carhart (1997). Monthly stock returns of individual firms are obtained from CRSP. Monthly series of $R M-R F, S M B, H M L$, and Momentum factors are obtained from 
Wharton Research Data Services. For the purpose of robustness, we present regression results for all of the five portfolio formations in Table 4, where the $t$ test statistics are calculated using Newey-West standard errors.

After controlling for the four risk factors, the highest CEI quartile portfolio has significant positive abnormal returns $(\alpha)$, while the lowest CEI quartile portfolio has negative abnormal returns. The difference between the highest CEI quartile portfolio and the lowest quartile portfolio returns is significantly positive. Using the first formation method as an example, a trading strategy of buying the highest CEI quartile stocks and selling the lowest CEI quartile stocks yields an abnormal return of $4.8 \%$ annually. Overall, the results in Table 4 indicate that firms with a higher level of corporate equality have higher future stock returns.

Hong and Kacperczyk (2009) find that stocks in the sin industries have higher returns, lower $\mathrm{Q}$, and lower price-earnings ratio. They argue that, applying the Gordon growth formula, $1 /(r-g)$, where $r$ is the discount rate and $g$ is the growth rate, the magnitude of excess return of sin stocks they find can basically match the magnitude of lower valuation of sin stocks. In our study, the value-enhancing hypothesis predicts that a company with a higher CEI score should have higher stock returns and better fundamentals (improved future cash flows), suggesting that a higher CEI score might be associated with a higher Q value. Following Hong and Kacperczyk (2009) and Gompers Ishii, and Metrick (2003), we specify the following model to test whether firms with higher CEI scores have higher Q.

$$
\begin{aligned}
Q_{i t}= & \alpha_{t}+\beta_{1} C E I_{i t}+\beta_{2} \log (\text { Total Assets })_{i t}+\beta_{3} \log (\text { age })_{i t}+\beta_{4} S \& P 500_{i t} \\
& +\beta_{5} \text { Delaware }_{i t}+\beta_{6}(R \& D / \text { Sales })_{i t}+\beta_{7} R O E_{i t}+\varepsilon_{i t},
\end{aligned}
$$

where $i$ stands for firm and $t$ for year. The dependent variable is $Q$, defined as the ratio of the market value of assets to the book value of assets. Explanatory variables are CEI plus the right-hand-side variables from Hong and Kacperczyk (2006) and Gompers Ishii, and Metrick (2003). $\log$ (Total Assets) is the natural logarithm of the book value of total assets. Delaware is a dummy set to one if a firm is headquartered in Delaware and zero elsewhere. $R O E$ is net income to the book value of equity. $R \& D /$ Sales is the $\mathrm{R} \& \mathrm{D}$ intensity in firm $i$, measured by $R \& D$ expenses divided by total sales, and is set to zero if $R \& D$ expenses are missing. ${ }^{8}$ Table 5 summarizes the results. Model (1) is the Fama-MacBeth regression results with industry fixed-effects. We first estimate the cross-sectional regressions with industry dummies using Equation (3) annually from 2002 to 2006, then report the time-series average values of the annual regression coefficients with time-series t-statistics calculated using Newey-West standard errors. Model (2) and Model (3) are pooled regressions with industry and year fixed effects separately. Model (4) is pooled regression including both industry and year fixed effects. Model (5) is a panel data model with firm fixed effects. From Model (2) to Model (5), heterskedasticity robust t-statistics are reported in parentheses under coefficients. In all models except Model (5), the coefficients of CEI are significantly positive, suggesting that the effect of CEI on Q is mostly a cross-sectional effect. Intuitively, firms with a higher CEI

\footnotetext{
${ }^{8} \mathrm{R} \& \mathrm{D}$ intensity is an important variable in estimating the effects of corporate social responsibility on financial performance. It can be partially controlled for by industry fixed effects. See McWilliams and Siegel (2000) and Waddock and Graves (1997).
} 
score also have a relatively higher market valuation (Q) compared to their peers. This result is consistent with the value-enhancing theory that a higher degree of corporate equality improves the fundamentals of firms, and therefore leads to higher stock returns and higher market valuation.

\subsection{How does corporate equality affect firm value?}

The previous section has documented that firms with a higher level of equality have higher firm value. A natural question arises: How does corporate equality translate into firm value? We offer two plausible explanations. The first explanation is the product-market channel: Consumers caring about social responsibility follow the HRC's or other media's recommendations and purchase products and services from firms with a higher level of corporate equality, leading to more sales and higher profitability, and, consequently, higher firm value (Heal, 2005). This product-market explanation predicts that firms with higher CEI scores should have more sales and better operating performance. The second explanation is the labor-market channel: A higher level of equality will attract more talent and promote morale. Better employee relations and high-quality employees can enhance productivity and promote innovation (Heal, 2005), translating into better fundamentals and higher firm value. In addition, the labor supply curve for firms with higher CEI scores will shift outward if workers value corporate equality and have stronger incentive to work in more equal firms. This will lead to more hiring in more equal firms, ceteris paribus. Therefore, the labormarket explanation predicts that firms with higher CEI scores have more advanced human capital, higher productivity, and more employees. To test the labor-market explanation, we would like to have detailed information on the quality of employees. However, given that our data contain no such information, we test only whether firms with higher CEI scores also have higher productivity (measured by total revenue per worker) and attract more employees. The section provides supportive empirical evidence for these two channels.

\subsubsection{Evidence from product markets}

The 1990 U.S. census, the first census containing sexual orientation information, reveals that gays and lesbians appear to receive higher education and higher earnings, compared to heterosexual counterparts (Black et al., 2000). It is not surprising to see that, during the past three decades, business interest has been gradually extended to a specific market segmentthe "gay market" (Baker, 1997). Although the exact number of GLBT population is unknown, the purchasing power of the gay market seems not negligible. The advocacy of corporate equality by the HRC would have had an impact on gay consumers; moreover, any consumers who value corporate equality, regardless of sexual orientation, would have supported firms with a higher level of equality, by purchasing products and services from them.

The annual report Buying for Equality, published by the HRC, advocates consumers to make informed choices to support companies that are more equal. ${ }^{9}$ According the HRC statement,

\footnotetext{
${ }^{9}$ For companies with a CEI score between 80 and 100, the guide rates them "the best places to shop" and advises that consumers "should make every effort to support these companies"; for companies with a CEI score below 45, the guide advises consumers to "avoid if possible"; and for companies with a CEI score between 46
} 
during 2006, "more than 250,000 people used Buying for Equality to make informed choices about their purchases." 10 Since many other advocates and human rights groups can also influence consumers who value social responsibility, presumably there have been enough consumers to influence product markets. We expect that firms with higher level of equality do better in product markets. Specifically, we expect that firms with higher CEI scores have higher sales and higher profit margins.

We specify the following model to test whether firms with higher CEI scores have more sales:

$$
\log (\text { Sales })_{i t}=\alpha_{t}+\beta_{1} C E I_{i t}+\beta_{2} \log (\text { age })_{i t}+\beta_{3} \log (B M)+\beta_{4} \log (\operatorname{Size})_{4}+\varepsilon_{i t},
$$

where the dependent variable is the logarithm of sales. The independent variables are a set of standard controls, as in Gompers, Ishii, and Metrick (2003) and Hong and Kacperczyk (2009). Size is the market value of equity. We also include industry-fixed effects, year-fixed effects or firm-fixed effects as additional controls.

Table 6 presents the estimated results. Similar to Table 5, Model (1) presents the FamaMacBeth regression results with industry fixed effects. Model (2), (3) and (4) are pooled OLS regressions with industry or year fixed effects, or both. Model (5) includes firm-fixed effects. As shown in Table 6, the coefficients of CEI are significantly positive in all models except in the model with only the year fixed effect, suggesting that it is important to control for industry differences when studying the effect of corporate equality on sales. After controlling for industry and year effects, a ten points increase in a firm's CEI score is associated with, on average, about $2.7 \%$ higher sales per year (column 4$).{ }^{11}$ It is worth noting that, even after controlling for firm fixed effects in Model (5), the coefficient of CEI is still significantly positive, similar to the Model (4) result. This strongly suggests that the effect of $\mathrm{CEI}$ on sales is not driven by unobserved firm heterogeneities.

Next, we examine whether firms with higher CEI scores have higher profit margins and specify the following model:

$$
\begin{aligned}
\text { Net profit margin }= & \alpha_{t}+\beta_{1} C E I_{i t}+\beta_{2} \log (B M)+\beta_{3} \log (\text { Size }) \\
& +\beta_{4} \log (\text { age })_{i t}+\beta_{5} \operatorname{Leverage}+\varepsilon_{i t},
\end{aligned}
$$

where the dependent variable Net Profit Margin is calculated as income before extraordinary items divided by sales, in percentage points. Similar to Tables 4 and 5, in Table 7 we report Fama-MacBeth, year fixed effects, industry fixed effects, and firm-fixed effects. Again, consistent with the product-market explanation, the coefficients of CEI are significantly

and 79, the HRC states that they "have taken steps toward a fair-minded workplace," and consumers are suggested to support them whenever possible.

${ }_{10}$ Quotes are from Buying For Equality 2007, available at http://www.hrc.org/buyersguide/index.asp.

${ }^{11} \mathrm{We}$ also use one-year sales growth as the dependent variable, but the coefficient is not significant in most cases. 
positive except in the firm-fixed effect model. After controlling for industry and year fixed effects, an increase in CEI by ten points is associated with a 0.13 percentage point increase in net profit margin.

\subsubsection{Evidence from labor markets}

A few studies on the wage gap between homosexual and heterosexual people find that gay men earn less compared to heterosexual males (Badgett, 1995; Blandford, 2003), suggesting that possibly there exists labor market discrimination against gays. Another different strand of literature on regional and urban economics constructs a gay index, the proportion of gay population in a location, to measure the openness and tolerance of local social milieu. Florida (2005) shows that cities with a higher gay index tend to attract more talented people and more high-tech industries. Using both the 1990 and 2000 U.S. decennial census data, Fu (2007) finds that cities with a higher gay index have higher housing prices and higher housing price growth. These studies suggest that migration is closely tied to the social equality, diversity, and tolerance of workplace and residential places. We expect anyone who believes in corporate equality would prefer working in companies with higher CEI scores, ceteris paribus. This will shift outward the labor supply curve for those companies. In addition, employees in companies that value equality tend to have stronger morale and can lead to higher productivity. For a given wage rate, those companies will increase demand, shifting the demand curve outward. The final effect should be an increase in hiring.

To test whether a higher level of corporate equality enhances workers' productivity, we use total revenue per employee as a proxy for a worker's productivity, and specify the following model:

$$
\begin{aligned}
\log (\text { Revenue per employee })_{i t}= & \alpha_{t}+\beta_{1} C E I_{i t}+\beta_{2} \log (\text { Age })_{i t}+\beta_{3} S \& P 500 \\
& +\beta_{4} \log (B M)_{i t}+\beta_{5} \text { Tangibility }_{i t}+\beta_{6} \log (\text { Size })_{i t} \\
& +\beta_{7}(R \& D / \text { Sales })_{i t}+\varepsilon_{i t} .
\end{aligned}
$$

The dependent variable is the logarithm of total revenue divided by the number of employees. The right side variables are a set of standard controls. Tangibility is measured by the value of the plant, property and equipment (data8) divided by total assets. The estimate results are presented in Table 8 . As expected, CEI is significantly positive in all model specifications except the model with only year fixed effects. When controlling both year and industry fixed effects, a ten points increase in CEI score is associated with a $1.8 \%$ increase in revenue per employee. This result is robust to the inclusion of firm fixed effects. The coefficient of Tangibility is negative in all model specifications, possibly because tangible assets are used more extensively in traditional manufacturing firms than in firms of high-tech and services industries, resulting in a lower productivity.

To test whether firms with higher CEI scores attract more employees, we estimate the following model:

$$
\begin{aligned}
\log \left(\text { Employee }_{i t}=\right. & \alpha_{t}+\beta_{1} C E I_{i t}+\beta_{2} \log (\text { Age })_{i t}+\beta_{3} S \& P 500+\beta_{4} \log (B M)_{i t} \\
& +\beta_{5} \text { Tangibility }_{i t}+\beta_{6} \log (\text { Size })_{i t}+\beta_{7}(R \& D / \text { Sales })_{i t}+\varepsilon_{i t},
\end{aligned}
$$


where the dependent variable is the logarithm of the number of total employees of firm $i$ in year $t$. We include firm age to control for the possibility that firms with a longer history are likely to have more employees. The book-to-market ratio is used to control for the effect of investment opportunities on employment. Since the level and types of technologies may also affect employment, we use Tangibility to control for the effects of nature of assets on employment. We also include industry, year, or firm fixed effects in some models.

Table 9 presents results for the impact of corporate equality on a firm's total employment. Consistent with the labor-market explanation, when controlling for both industry and year fixed effects, the coefficient of CEI is significantly positive. An increase in the CEI score by ten points is associated with $1.9 \%$ higher total employment.

In summary, we find that the effect of corporate equality on firm value comes from two channels: First, firms with a higher level of equality are favored by consumers and, therefore, perform better in terms of sales and profit margin. Second, firms providing a more equal environment can attract more motivated employees and enhance workers' productivity, leading to a higher firm value.

\subsection{Endogeneity issue}

One concern about our study is that some unobserved firm characteristics could be correlated with the CEI variable, biasing the estimate of the coefficient of CEI. The typical argument would be that good management is positively correlated with CEI. For example, firms with good management may tend to implement more equal corporate policies, therefore, resulting in the spurious correlation between corporate equality and firm value. We deal with such an endogeneity issue in two ways.

First, we estimate the previous models using a panel data approach, including firm fixed effects, whenever possible. This provides the most conservative estimates. Column 5 in Table 6 and Table 8 shows that, after controlling for firm fixed effects, CEI scores still have positive and significant effects on sales and productivity. Column 5 in Table 5 and Table 9 shows that, after controlling for firm fixed effects, CEI scores have positive effects on Q and employment, although not significant. One exception is Column 5 in Table 7, where inclusion of firm fixed effects leads to negative effects of CEI scores on profit margins, but not significant. Cumulatively, all these firm fixed effects models lend some support to the argument that the endogeneity issue might exist, but is not a serious problem. ${ }^{12}$

Our second approach is to find a proxy for good management, and test whether the CEI is really positively correlated with the proxy. We use the rank of "Fortune 100 Best Companies to Work For in America" as a proxy for management quality. The data are constructed by the Great Place to Work Institute and are available at www.greatplacetowork.com. The ranking is based on three dimensions: The relationship between employees and management, between employees and their jobs/company, and between employees and other

\footnotetext{
${ }^{12}$ One possible reason that the firm fixed-effect results are not very strong is due to the fact that the time-series variation in the CEI score is not large enough: nearly $60 \%$ of yearly changes are zeros.
} 
employees. ${ }^{13}$ It is reasonable to assume that good management produces those three types of relationships, and, therefore, management quality should be positively correlated with the great-place-to-work ranking. Out of our sample of 1,283 firm years, 142 firm years have great-place-to-work rankings. We find that the rankings and the CEI index is negatively correlated (-0.178) and significant at the 5\% level, which suggests that better management does not necessarily produce a higher CEI score. We also run the tests using great-place-towork rankings instead of CEI scores. In unreported tables, the coefficients of great-place-towork rankings are either insignificant or have the opposite signs. In general, we do not find that management quality can explain the effects of CEI, documented in the previous tables. Therefore, we tentatively conclude that endogeneity is not a serious problem to our previous estimates.

\section{What determines the CEI score?}

In the previous two sections, we have provided evidence that firms with a higher level of equality have higher value. Another natural question arises: What firm and industry characteristics determine a firm's level of corporate equality? While it is hard to predict theoretically the association between a certain firm and industry characteristics and the CEI score, anecdotal evidence shows that harsh competition in an industry will motivate firms to increase their corporate equality practice. For example, Coca-Cola achieved a full score of 100 in 2006 while RadioShack Corp. had a score of 40 in $2006 .{ }^{14} \mathrm{We}$ hypothesize that firms in more competitive industries tend to achieve higher CEI scores. We use the Herfindal index to measure industry competitiveness and specify the following model to test the competition hypothesis:

$$
\begin{aligned}
C E I_{i t}= & \alpha_{t}+\beta_{1}(S \& P 500)_{i t}+\beta_{2} \log (\text { Age })_{i t}+\beta_{3} \log (\text { Size })_{i t}+\beta_{4} \log (B M)_{i t} \\
& +\beta_{5}(R \& D / \text { Sales })+\beta_{6} \text { Leverage }+\beta_{7} \text { Herfindal }_{t}+\varepsilon_{i t} .
\end{aligned}
$$

The estimate results are shown in Table 10. The coefficients of the Herfindal index are insignificant. Instead, after controlling for industry, year, and state fixed effects, we find that firm size, $\mathrm{R} \& \mathrm{D} / \mathrm{sales}$, and leverage have significant positive effects on corporate equality. Intuitively, larger firms are more visible to the public and have a greater need to demonstrate that they are good employers. Firms with higher R\&D expenses usually have a greater demand for more skillful employees, and therefore, have a greater need to achieve a higher level of corporate equality to attract talent. The positive effect of leverage on corporate equality can be explained in two ways. First, firms with a higher leverage usually have more interactions with external capital markets. As a result, firms with a higher leverage either are more equal or are required to show that they are more equal. Second, Jensen (1986) argues that higher leverage can put more pressure on managers and force managers to achieve better performance. Therefore, firms with a higher leverage will be more motivated to adopt equality policies to attract good employees. In unreported tables, we also add a sin dummy to indicate sin industries. The coefficients of the sin dummy are significantly positive in some

\footnotetext{
${ }^{13}$ The quote is from http://www.greatplacetowork.com/great/index.php.

${ }^{14}$ The Herfindahl index for food \& kindred products (SIC 20) and home furniture \& furnishing stores (SIC 57) in 2006 are 0.05 and 0.25 , respectively. The mean value of the Herfindal index across industries in 2006 is 0.07 .
} 
specifications and are insignificant with year, industry, and state fixed effects. Adding the sin dummy does not affect coefficients of other variables. In general, the intuition from the results in Table 10 is that firms have a higher level of corporate equality because they are either in need of a good public image or in need of attracting talented employees. We also notice that firm age has a negative effect on corporate equality in most regressions, and a positive effect in firm-fixed effect models. This suggests that, cross-sectionally, older firms are more resistant to, while younger firms are more receptive to, equality policies. However, for a given firm, its level of corporate equality increases as time goes by (i.e., as the firm gets older). While these results are intuitive, the exact mechanisms cannot be revealed, given our data sets, and need further investigation.

\section{Conclusion}

Many studies have shown that social norms affect firm performance, but the empirical results are inconclusive. Our study contributes to the literature by testing directly how and through what channels a specific type of social responsibility-corporate equality-affects capital market performance. We find that firms with a higher degree of corporate equality also have, on average, higher returns and market value. The association can be explained by the empirical evidence from product markets and labor markets: Firms with a high CEI score also tend to have larger sales, higher productivity in terms of revenue per employee, and attract more employees, probably because consumers and employees value corporate equality. We also apply a panel data, firm fixed effect approach to control for firm heterogeneities and the results generally confirm the previous findings. The overall results suggest that markets do value corporate equality. Our results are similar to those in Gompers, Ishii, and Metrick (2003), that firms with more democratic corporate governance (stronger shareholder rights) had higher firm value, higher profits, and higher sales growth. Our findings should be useful for people to make decisions on corporate-equality-related investment, marketing and advertising, and hiring issues.

Our study can be extended in various directions. First, as institutional investors hold less sin stocks (Hong and Kacperczyk, 2009), they might hold more stocks of companies with high CEI scores or that are more socially responsible. Therefore, testing the institutional ownership of socially responsible stocks is of great interest. Second, the channels through which corporate equality enhances firm performance could be interpreted in more detail if more data are available. For example, does corporate equality help attract more skilled workers? Finally, the effect of corporate equality, and, in general, social responsibility, on capital market performance may also affect corporate financing behavior (Hong and Kacperczyk, 2009), which is also worth further investigation.

\section{References}

Badgett, M. V. Lee, 1995, The wage effects of sexual orientation discrimination, Industrial and Labor Relation Review 48, 726-739. 
Baker, D., 1997, A history in ads: The growth of the gay and lesbian market. In Gluckman, A., and Reed, B., (Eds.), Homo Economics, Routledge, New York, pp.12-20.

Bauer, R., Koedijk, K., Otten, R., 2005, International evidence on ethical mutual fund performance and investment style, Journal of Banking and Finance 29, 1751-1767.

Bello, Z., 2005, Socially responsible investing and portfolio diversification, Journal of Financial Research 28, 41-57.

Black, D., Gates, G., Sanders, S., Taylor, L., 2000, Demographics of the gay and lesbian population in the United States: Evidence from available systematic data sources, Demography 37, 139-154.

Blandford, J., 2003, The nexus of sexual orientation and gender in the determination of earnings, Industrial and Labor Relations Review 56, 622-642.

Carhart, M., 1997, On persistence in mutual fund performance, The Journal of Finance 52, 41-57.

Fama, E., French, K. 1992. The cross-section of expected stock returns, Journal of Finance. 427-465.

Fama, E. and French, K. 1993. Common risk factors in the returns on stocks and bonds". Journal of Financial Economics 33, 3-56.

Fama, E. and French, K. 1997. Industry costs of equity. Journal of Financial Economics, 153-193.

Fama, Eugene F. and MacBeth, J.D., 1973. Risk, return, and equilibrium: empirical test. Journal of Political Economy 81, 607-636.

Florida, R., 2005, Cities and the creative class, Routledge, New York.

Fu, S., 2007, Sexual orientation and neighborhood quality: Do same-sex couples make better communities? Working Paper.

Geczy, C., Stambaugh, R., Levin, D., 2005, Investing in socially responsible mutual funds, Working Paper, University of Pennsylvania, Wharton School.

Goldreyer, E., Diltz, D., 1999, The performance of socially responsible mutual funds: Incorporating sociopolitical information in portfolio selection, Managerial Finance 25, 23-36.

Gompers, P., Ishii, J., and Metrick, A., 2003, Corporate governance and equity price, Quarterly Journal of Economics 118, 107-155. 
Hamilton, S., Jo, H., Statman, M., 1993, Doing well while doing good? The investment performance of socially responsible mutual funds, Financial Analysis Journal, NovemberDecember, 62-65.

Heal, G., 2005, Corporate social responsibility: An economic and financial framework, The Geneva Papers on Risk and Insurance - Issues and Practice 30, 387-409.

Hong, H., Kacperczyk, M., 2009, The price of sin: The effects of social norms on markets, Journal of Financial Economics, forthcoming.

Hou, K. and, David T. Robinson, 2006. Industry concentration and average stock returns, Journal of Finance, 1927-1956.

Jensen, Michael C, 1986. Agency Costs of Free Cash Flow, Corporate Finance, and Takeovers, American Economic Review, vol. 76(2), p323-329.

Kempf, A., Osthoff, P., 2007, The effect of socially responsible investing on portfolio performance, European Financial Management 13, 908-922.

Kerr, W., Fu, S., 2008, The survey of industrial R\&D-patent database link project, Journal of Technology Transfer 33, 173-186.

Lev, B., Petrovits, C., Radhakrishnan, S., 2006, Is doing good good for you? Yes, charitable contributions enhance revenue growth, Working Paper, New York University, Stern School of Business.

Mallin, C., Saadouni, B., Briston, R., 1995, The financial performance of ethical investment funds, Journal of Business Finance and Accounting 22, 483-496.

Margolis, J., Elfenbein, H., Walsh, J., 2007, Does it pay to be good? A meta-analysis and redirection of research on the relationship between corporate social and financial performance, Working Paper, Harvard Business School.

McWilliams, A., Siegel, D., 2000, Corporate social responsibility and financial performance: Correlation or Misspecification? Strategic Management Journal 21, 603-608.

Renneboog, L., Horst, J. T., Zhang, C., 2008, The price of ethics and stakeholder governance: The performance of socially responsible mutual funds, Journal of Corporate Finance 14, 302-322.

Sauer, D., 1997, The impact of social-responsibility screens on investment performance: Evidence from the Domini 400 social index and Domini equity mutual fund, Review of Financial Economics 6, 137-149.

Statman, M., 2000, Socially responsible mutual funds, Financial Analysts Journal, May/June, 30-39. 
Statman, M., 2006, Socially responsible indexes, Journal of Portfolio Management, Spring, 100-109

Statman, M., 2007, Socially responsible investment, Working Paper, Santa Clara University.

Waddock, S., Graves, S., 1997, The corporate social performance-financial performance link, Strategic Management Journal 18, 303-319. 
Table 1 Summary statistics

This table summarizes statistics of 1,283 firm years with the Corporate Equality Index (CEI) which are listed in both Compustat and CRSP from 2002 to 2006. Q is the ratio of the market value of assets to the book value of assets. Age is the number of years available in CRSP. $\log ($ Sales $)$ is the logarithm of sales. $\log ($ Employee) is the logarithm of the number of employees. Herfindahl index is the sum of squared sales-based market shares of all firms in Compustat in a 2-digit SIC industry in a given year, and its value lies between 0 and 1. $\log (\mathrm{BM})$ is the logarithm of the ratio of book value of equity to the market value of equity. Net profit margin is income before extraordinary items divided by sales. Leverage is the ratio of total debt divided by the sum of total debt and book value of equity. S\&P 500 Firm is a dummy set to one if a firm is included in the S\&P 500 index and zero elsewhere. ROE is earnings to the book value of equity.

Panel A: descriptive statistics of CEI

\begin{tabular}{lcccccc}
\hline & $\mathrm{N}$ & Mean & Median & Min & Max & Std \\
\hline 2002 & 214 & 60.61 & 57.00 & 0.00 & 100.00 & 23.71 \\
2003 & 253 & 68.92 & 71.00 & 14.00 & 100.00 & 21.77 \\
2004 & 262 & 71.96 & 79.00 & 0.00 & 100.00 & 22.85 \\
2005 & 276 & 76.30 & 86.00 & 14.00 & 100.00 & 21.53 \\
2006 & 278 & 75.94 & 80.00 & 0.00 & 100.00 & 25.33 \\
Total & 1,283 & 71.26 & 75.00 & 0.00 & 100.00 & 23.69 \\
\hline
\end{tabular}

Panel B: descriptive statistics of variables

\begin{tabular}{lcccccc}
\hline & $\begin{array}{c}\text { Correlation } \\
\text { with CEI }\end{array}$ & Mean & Median & Minimum & Maximum & Std Dev \\
\hline $\mathrm{Q}$ & 0.029 & 1.863 & 1.476 & 0.866 & 6.117 & 1.045 \\
Log(Total assets) & 0.300 & 9.821 & 9.692 & 6.159 & 14.050 & 1.686 \\
Age & -0.105 & 34.122 & 31.000 & 1.000 & 81.000 & 24.331 \\
Log(Sales) & 0.194 & 9.349 & 9.279 & 6.118 & 12.270 & 1.214 \\
Log(Employee) & 0.102 & 3.531 & 3.630 & 0.182 & 6.035 & 1.229 \\
Herfindal & -0.067 & 0.065 & 0.042 & 0.009 & 0.309 & 0.061 \\
Log(BM) & -0.003 & -0.976 & -0.916 & -3.447 & 0.634 & 0.717 \\
Net Profit Margin & 0.165 & 0.077 & 0.069 & -0.204 & 0.305 & 0.077 \\
Leverage & 0.028 & 0.417 & 0.402 & 0.000 & 0.960 & 0.261 \\
S\&P 500 & 0.125 & 0.775 & 1.000 & 0.000 & 1.000 & 0.418 \\
ROE & -0.048 & 0.157 & 0.146 & -1.077 & 1.718 & 0.281 \\
\hline
\end{tabular}


Table 2 Cross-section of average stock returns

This table presents average monthly returns, in percentage points, of quartile portfolios from January 2002 to December 2006. Each year, the CEI score of each firm is matched with 12 months of stock returns using five methods with different lags between CEI year and future stock returns. 1) Matching CEI in year $t$ with monthly returns from January to December of year t. 2) Matching CEI in year $t$ with monthly returns from October of year $t$ to September of year $t+1$, where October is the month following the release of new CEI scores; 3 ) Matching CEI in year $t$ with monthly returns from January to December of year $t+1 ; 4$ ) Matching CEI in year $t$ with monthly returns from July of year $t+1$ to June of year $t+2 ; 5$ ) Matching first-year CEI with monthly returns in consequent years, skipping the first-year returns. Each year, the CEI scores are sorted into quartiles. Equally-weighted, monthly, quartile portfolio returns are calculated each month. Average monthly quartile portfolio returns are presented in the table. T-statistics calculated using Newey-West standard errors are in parentheses.

\begin{tabular}{lccc}
\multicolumn{4}{c}{ Quartile (CEI rankings in year $\mathrm{t}$ ) } \\
\hline 1 Low & 2 & 3 & 4 High
\end{tabular}

Formation 1: CEI in year $t$ matched with monthly returns from January to December of year $\mathrm{t}$
0.9422
0.9249
1.1207
1.2362
0.2940
(3.047)
$(2.432)$
(4.770)
$(3.522)$
(2.519)

Formation 2: CEI in year $\mathrm{t}$ matched with monthly returns from October of year $\mathrm{t}$ to September of year $\mathrm{t}+1$

$\begin{array}{lllll}1.4241 & 1.6988 & 1.7073 & 2.0293 & 0.6052 \\ (6.836) & (4.718) & (6.464) & (4.823) & (2.580)\end{array}$

Formation 3: CEI in year $\mathrm{t}$ matched with monthly returns from January to December of year $\mathrm{t}+1$
1.3211
1.6426
1.5933
1.8506
0.5295
(8.114)
(4.933)
(6.599)
(5.925)
$(2.866)$

Formation 4: CEI in year $\mathrm{t}$ matched with monthly returns from July of year $\mathrm{t}+1$ to June of year $\mathrm{t}+2$
1.2468
1.4023
1.5420
1.5250
0.2782
(7.755)
(6.429)
$(7.753)$
(6.496)
(2.671)

Formation 5: First year CEI matched with monthly returns in consequent years, skipping the first year returns

$\begin{array}{lllll}1.0969 & 1.4784 & 1.3908 & 1.4431 & 0.3462 \\ (5.871) & (4.277) & (4.139) & (4.895) & (2.785)\end{array}$


Table 3 CEI index and stock return performance $2002-2006$

This table summarizes results from Fama-MacBeth cross-sectional regressions explaining monthly stock returns from January of 2002 to December of 2006. The dependent variable is monthly stock returns in percentage points. Accounting data in year $t$ are matched with monthly stock returns from July of year $t+1$ to June of year $t+2$. Size is the market value of equity in June of year $\mathrm{t}+1$. BM is the book value of equity divided by the market value of equity. Momentum is the previous twelve months' returns. Beta is the market model beta estimated using the prior 36 monthly, value-weighted, CRSP index returns. Leverage is total debt divided by market value of total assets. Each year, the CEI score of each firm is matched with 12 months of stock returns using five methods with different lags between CEI year and future stock returns. 1) Matching CEI in year t with monthly returns from January to December of year t. 2) Matching CEI in year $t$ with monthly returns from October of year $t$ to September of year $t+1$, where October is the month following the release of new CEI scores; 3 ) Matching CEI in year $t$ with monthly returns from January to December of year $t+1$; 4) Matching CEI in year $t$ with monthly returns from July of year $t+1$ to June of year $\mathrm{t}+2$; 5) Matching first year CEI with monthly returns in consequent years, skipping the firstyear returns. Time-series average values of the monthly regression coefficients are reported with time-series t-statistics calculated using Newey-West standard errors (in parentheses). Constants are not reported. ${ }^{* *}, * *$, and $*$ denote significance at the $1 \%, 5 \%$ and $10 \%$ levels.

\begin{tabular}{cccccc}
\hline & $(1)$ & $(2)$ & $(3)$ & $(4)$ & $(5)$ \\
\hline CEI & $0.0050^{* * *}$ & $0.0055^{* *}$ & $0.0038^{*}$ & $0.0031^{*}$ & $0.0040^{*}$ \\
& $(3.547)$ & $(2.367)$ & $(1.745)$ & $(1.803)$ & $(1.826)$ \\
$\log ($ size $)$ & $-0.1415^{* *}$ & $-0.1647^{*}$ & -0.1326 & -0.1004 & $-0.1504^{*}$ \\
& $(-2.602)$ & $(-1.84)^{* *}$ & $(-1.481)$ & $(-1.585)$ & $(-1.816)^{* *}$ \\
$\log (\mathrm{BM})$ & $0.2526^{* * *}$ & $0.3205^{* * *}$ & $0.3655^{* * *}$ & $0.3888^{* * *}$ & $0.3446^{* * *}$ \\
& $(4.020)$ & $(4.060)$ & $(4.879)$ & $(3.695)$ & $(2.907)$ \\
Momentum & $-0.7641^{* *}$ & -1.0501 & -0.6607 & -0.0919 & -0.4733 \\
& $(-2.027)$ & $(-1.457)$ & $(-1.230)$ & $(-0.316)$ & $(-0.624)$ \\
Beta & 0.0641 & 0.4544 & 0.2586 & 0.1094 & 0.2705 \\
& $(0.380)$ & $(1.490)$ & $(1.213)$ & $(0.833)$ & $(0.908)$ \\
Leverage & 0.2485 & 0.0652 & 0.0349 & -0.0147 & 0.0437 \\
& $(1.336)$ & $(0.239)$ & $(0.122)$ & $(-0.0383)$ & $(0.100)$ \\
Number of months & 60 & 51 & 48 & 42 & 48 \\
Total observations & 15387 & 12753 & 11812 & 10040 & 11884 \\
Adj R $\mathrm{R}^{2}$ & 0.095 & 0.093 & 0.079 & 0.074 & 0.079 \\
\hline
\end{tabular}


Table 4 Performance of quartile portfolios

This table summarizes regression results of portfolios sorted by CEI from January of 2002 to December of 2006. The dependent variable is the equally-weighted, monthly, quartile portfolio returns minus the risk-free rate in percentage points. Each year, the CEI score of each firm is matched with 12 months of stock returns using five methods with different lags between CEI year and future stock returns. 1) Matching CEI in year $t$ with monthly returns from January to December of year t. 2) Matching CEI in year $t$ with monthly returns from October of year $t$ to September of year $t+1$, where October is the month following the release of new CEI scores ; 3) Matching CEI in year $t$ with monthly returns from January to December of year $t+1$; 4) Matching CEI in year $t$ with monthly returns from July of year $t+1$ to June of year $\mathrm{t}+2$; 5) Matching first year CEI with monthly returns in consequent years, skipping the first-year returns. Each year, CEI scores are sorted into quartiles, and equallyweighted quartile portfolio returns are calculated. RM- RF, SMB, HML and Momentum are risk factors defined by Fama and French (1993) and Carhart (1997). T-statistics calculated using Newey-West standard errors are in parentheses.

\begin{tabular}{llccc}
\hline & \multicolumn{4}{c}{ Quartile (CEI rankings in year t) } \\
\cline { 2 - 4 } & 2 & 3 & 4 High
\end{tabular}

Formation 1: CEI in year $\mathrm{t}$ matched with monthly excess returns from January of year $\mathrm{t}$ to December of year $\mathrm{t}$

\begin{tabular}{cccccc}
$\alpha$ & -0.042 & -0.063 & 0.188 & 0.356 & 0.397 \\
& $(-0.89)$ & $(-0.88)$ & $(2.40)$ & $(2.55)$ & $(3.20)$ \\
RM-RF & 102.135 & 97.882 & 89.564 & 107.552 & 5.417 \\
& $(28.3)$ & $(40.0)$ & $(43.6)$ & $(51.7)$ & $(1.58)$ \\
SMB & 24.407 & 26.383 & 31.843 & 11.085 & -13.322 \\
& $(3.80)$ & $(2.19)$ & $(2.06)$ & $(2.42)$ & $(-4.21)$ \\
\multirow{2}{*}{ HML } & 14.815 & 30.531 & 14.808 & 25.660 & 10.846 \\
& $(3.91)$ & $(15.2)$ & $(5.80)$ & $(7.37)$ & $(2.95)$ \\
Momentum & -2.673 & -23.622 & -15.155 & -30.780 & -28.107 \\
& $(-0.89)$ & $(-10.0)$ & $(-6.30)$ & $(-11.2)$ & $(-6.48)$
\end{tabular}

Formation 2: CEI in year $t$ matched with monthly excess returns from October of year $t$ to September of year $\mathrm{t}+1$

$\begin{array}{cccccc}\alpha & -0.192 & -0.084 & 0.071 & 0.253 & 0.445 \\ & (-1.99) & (-0.77) & (0.47) & (4.49) & (3.86) \\ \text { RM-RF } & 101.390 & 90.005 & 98.176 & 112.453 & 11.063 \\ & (21.9) & (23.7) & (22.1) & (44.5) & (2.39) \\ \text { SMB } & 15.520 & 26.936 & 16.619 & 2.962 & -12.558 \\ & (4.41) & (2.34) & (1.33) & (0.76) & (-2.52) \\ \text { HML } & 13.542 & 39.959 & 13.659 & 17.939 & 4.396 \\ & (3.95) & (5.99) & (1.64) & (3.75) & (1.40) \\ \text { Momentum } & -2.581 & -30.167 & -15.142 & -19.596 & -17.015 \\ & (-0.75) & (-10.2) & (-5.85) & (-3.94) & (-2.64)\end{array}$

Formation 3: CEI in year $t$ matched with monthly excess returns in from January of year $\mathrm{t}+1$ to December of year $\mathrm{t}+1$

$\begin{array}{llllll}\alpha & -0.195 & 0.064 & 0.177 & 0.222 & 0.417\end{array}$




\begin{tabular}{cccccc}
\hline \multirow{3}{*}{ RM-RF } & $(-1.69)$ & $(0.67)$ & $(1.43)$ & $(2.37)$ & $(5.49)$ \\
& 99.553 & 109.308 & 107.841 & 114.575 & 15.022 \\
SMB & $(23.0)$ & $(12.5)$ & $(25.9)$ & $(52.2)$ & $(3.66)$ \\
& 13.645 & -2.296 & -4.338 & 4.350 & -9.296 \\
HML & $(3.59)$ & $(-0.60)$ & $(-0.68)$ & $(0.37)$ & $(-0.72)$ \\
& 12.617 & 17.848 & -3.031 & 12.371 & -0.247 \\
Momentum & $(3.17)$ & $(5.23)$ & $(-0.50)$ & $(1.98)$ & $(-0.043)$ \\
& -4.641 & -19.905 & -8.735 & -6.580 & -1.939 \\
& $(-1.12)$ & $(-6.77)$ & $(-2.26)$ & $(-2.03)$ & $(-0.40)$
\end{tabular}

Formation 4: CEI in year $t$ matched with monthly excess returns from July of year $t+1$ to June of year $\mathrm{t}+2$

$\begin{array}{cccccc}\alpha & -0.114 & 0.220 & 0.274 & 0.200 & 0.314 \\ & (-2.00) & (3.45) & (2.04) & (2.05) & (2.58) \\ \text { RM-RF } & 101.599 & 94.841 & 95.606 & 121.782 & 20.183 \\ & (29.2) & (15.2) & (38.1) & (55.8) & (4.32) \\ \text { SMB } & 7.443 & -5.940 & 5.852 & -13.380 & -20.823 \\ & (1.30) & (-1.40) & (0.56) & (-1.16) & (-1.33) \\ \text { HML } & 19.541 & 20.459 & 18.808 & -5.899 & -25.440 \\ & (4.58) & (6.36) & (1.43) & (-0.85) & (-5.22) \\ \text { Momentum } & -11.009 & -10.971 & -20.932 & 8.342 & 19.351 \\ & (-2.38) & (-2.06) & (-4.10) & (1.64) & (5.36)\end{array}$

Formation 5: First-year CEI matched with monthly excess returns in consequent years, skipping the first-year returns

\begin{tabular}{cccccc}
$\alpha$ & -0.139 & 0.100 & 0.095 & 0.078 & 0.217 \\
& $(-0.80)$ & $(1.01)$ & $(1.60)$ & $(0.69)$ & $(2.38)$ \\
RM-RF & 98.293 & 114.141 & 100.138 & 111.924 & 13.631 \\
& $(16.5)$ & $(18.2)$ & $(15.9)$ & $(51.9)$ & $(2.32)$ \\
SMB & 2.649 & -0.885 & 3.260 & 4.789 & 2.140 \\
& $(0.62)$ & $(-0.19)$ & $(0.66)$ & $(0.55)$ & $(0.28)$ \\
HML & 14.560 & 7.324 & 19.070 & 4.335 & -10.225 \\
& $(2.97)$ & $(1.00)$ & $(2.29)$ & $(0.69)$ & $(-1.05)$ \\
Momentum & -6.668 & -17.429 & -12.228 & -12.218 & -5.549 \\
& $(-1.31)$ & $(-7.39)$ & $(-1.86)$ & $(-5.19)$ & $(-0.85)$ \\
\hline
\end{tabular}


Table 5 Firm value and CEI index

This table summarizes the results of regressions for a sample of 1,283 firm years from 2002 to 2006. The dependent variable is Q, defined as the ratio of the market value of assets to the book value of assets. CEI is the Corporate Equality Index. Log(Total assets) is the natural logarithm of the book value of total assets. $\log ($ Age) is the logarithm of firm age, measured by the number of years available in CRSP. S\&P 500 Firm is a dummy set to one if a firm is included in the S\&P 500 index, and zero otherwise. Delaware Firm is a dummy set to one if a firm is headquartered in Delaware and zero otherwise. ROE is net income to the book value of equity. $R \& D /$ Sales is $R \& D$ over sales where missing $R \& D$ data are set to zero. For Fama-MacBeth regressions, industry-fixed effects are included and time-series average values of the annual regression coefficients are reported with time-series t-statistics calculated using Newey-West standard errors in parentheses. For other regressions, tstatistics calculated using standard errors corrected for heteroskedasticity are reported in parentheses. Constants are not reported. Industries are 48 industries classified by FamaFrench (1997). ${ }^{* * *}, * *$, and $*$ denote significance at the $1 \%, 5 \%$ and $10 \%$ levels.

\begin{tabular}{cccccc}
\hline & \multicolumn{5}{c}{$\mathrm{Q}$} \\
\cline { 2 - 6 } CEI & $(1) \mathrm{FM}$ & $(2)$ & $(3)$ & $(4)$ & $(5)$ \\
& $0.0028^{* * *}$ & $0.0028^{* * *}$ & $0.0026^{* * *}$ & $0.0025^{* * *}$ & 0.0011 \\
Log(Total assets) & $(6.428)^{* * *}$ & $(3.162)^{* * *}$ & $(2.854)^{* * *}$ & $(2.774)^{* * *}$ & $(1.347)^{* * *}$ \\
& $-0.1009^{* *}$ & $-0.1031^{*}$ & $-0.1797^{* *}$ & $-0.1029^{* *}$ & $-0.3514^{* *}$ \\
Log(Age) & $(-5.166)$ & $(-6.671)^{* * *}$ & $(-14.44)^{* *}$ & $(-6.658)^{* * *}$ & $(-3.191)$ \\
& $-0.1210^{* * *}$ & $-0.1125^{* * *}$ & $-0.0810^{* *}$ & $-0.1151^{* * *}$ & $0.4381^{* * *}$ \\
S\&P 500 & $(-7.266)^{* *}$ & $(-3.283)$ & $(-2.383)$ & $(-3.332)$ & $(4.265)$ \\
& $0.2388^{* * *}$ & $0.2262^{* * *}$ & $0.2252^{* * *}$ & $0.2329^{* * *}$ & - \\
Delaware Firm & $(7.209)$ & $(3.411)$ & $(3.460)$ & $(3.499)$ & \\
& $0.1891^{* *}$ & 0.0578 & -0.1925 & 0.0659 & - \\
R\&D/Sales & $(3.599)$ & $(0.399)$ & $(-0.973)$ & $(0.465)$ & \\
& $8.7508^{* * *}$ & $8.4575^{* * *}$ & $8.1062^{* * *}$ & $8.4889^{* * *}$ & $-4.2733^{* *}$ \\
ROE & $(15.71)^{* * *}$ & $(8.489)$ & $(13.02)$ & $(8.504)$ & $(-1.987)$ \\
& $1.5283^{* * *}$ & $1.3930^{* * *}$ & $1.5657^{* * *}$ & $1.3824^{* * *}$ & $0.4703^{* * * *}$ \\
Fama-MacBeth & $(23.73)$ & $(11.36)$ & $(12.54)$ & $(11.19)$ & $(5.471)$ \\
Industry-fixed effects & Yes & - & - & - & - \\
Year-fixed effects & - & Yes & - & Yes & - \\
Firm-fixed effects & - & - & Yes & Yes & - \\
$\mathrm{N}$ & 1283 & 1283 & 1283 & 1283 & 1283 \\
Adj R ${ }^{2}$ & 0.482 & 0.525 & 0.447 & 0.524 & 0.897 \\
\hline
\end{tabular}


Table 6 Product market evidence - Sales and CEI index

This table summarizes the results of regressions of sales on the CEI and control variables, for a sample of 1,283 firm years from 2002 to 2006. The dependent variable is the natural logarithm of sales. $\log (\mathrm{BM})$ is the natural logarithm of the book value of equity divided by the market value of equity. $\log (\mathrm{Age})$ is the natural logarithm of firm age, measured by the number of years available in CRSP. $\log (\mathrm{Size})$ is the natural logarithm of market capitalization, calculated as the natural logarithm of the market value of equity at the end of year $t$. For Fama-MacBeth regressions, industry-fixed effects are included and time-series average values of the annual regression coefficients are reported with time-series t-statistics calculated using Newey-West standard errors in parentheses. For other regressions, tstatistics calculated using standard errors corrected for heteroskedasticity are reported in parentheses. Constants are not reported. Industries are 48 industries classified by FamaFrench (1997). ${ }^{* * *}, * *$, and $*$ denote significance at the $1 \%, 5 \%$ and $10 \%$ levels.

\begin{tabular}{cccccc}
\hline & \multicolumn{5}{c}{$\log ($ Sales $)$} \\
\cline { 2 - 6 } CEI & $(1) \mathrm{FM}$ & $(2)$ & $(3)$ & $(4)$ & $(5)^{* * *}$ \\
& $0.0019^{* * *}$ & $0.0023^{* * *}$ & -0.0004 & $0.0027^{* * *}$ & $0.0026^{* * *}$ \\
Log(Age) & $(7.389)$ & $(2.768)$ & $(-0.401)$ & $(3.266)$ & $(4.833)^{* *}$ \\
& 0.0254 & 0.0215 & $0.0807^{* *}$ & 0.0221 & $0.4918^{* * *}$ \\
Log(BM) & $(0.982)^{* *}$ & $(0.833)^{* *}$ & $(2.570)^{* *}$ & $(0.856)^{* *}$ & $(5.912)^{* *}$ \\
& $0.4257^{* * *}$ & $0.4444^{* * *}$ & $0.4994^{* *}$ & $0.4381^{* *}$ & $0.1086^{* * *}$ \\
Log(Size) & $(25.82)^{* *}$ & $(14.02)^{* *}$ & $(16.70)$ & $(13.78)^{* * *}$ & $(3.114)^{* *}$ \\
& $0.7455^{* * *}$ & $0.7198^{* * *}$ & $0.6834^{* * *}$ & $0.7208^{* * *}$ & $0.1689^{* * *}$ \\
Fama-MacBeth & $(39.86)$ & $(32.43)$ & $(17.01)$ & $(32.20)$ & $(2.595)$ \\
Industry-fixed effects & Yes & - & - & - & - \\
Year-fixed effects & - & Yes & - & Yes & - \\
Firm-fixed effects & - & - & Yes & Yes & - \\
$\mathrm{N}$ & 1283 & 1283 & 1283 & - & Yes \\
Adj R & 0.792 & 0.795 & 0.665 & 0.796 & 1283 \\
\hline
\end{tabular}


Table 7 Product market evidence- Profit margin and CEI index

This table summarizes the results of regressions of profit margin on the CEI and control variables for a sample of 1,283 firm years from 2002 to 2006 . The dependent variable is net profit margin, in percentage points, and earnings to total assets (ROA), in percentage points. $\log (\mathrm{BM})$ is the natural logarithm of book value of equity divided by market value of equity. $\log$ (Age) is the log of firm age, measured by the number of years available in CRSP. $\log ($ Size $)$ is the $\log$ of market capitalization, calculated as the natural logarithm of the market value of equity at the end of year $t$. Leverage is the total debt divided by the market value of total assets. For Fama-MacBeth regressions, industry-fixed effects are included and time-series average values of the annual regression coefficients are reported with time-series t-statistics calculated using Newey-West standard errors in parentheses. For other regressions, t-statistics calculated using standard errors corrected for heteroskedasticity are reported in parentheses. Constants are not reported. Industries are 48 industries classified by Fama-French (1997). ${ }^{* * *}, * *$, and $*$ denote significance at the $1 \%, 5 \%$ and $10 \%$ levels.

\begin{tabular}{|c|c|c|c|c|c|}
\hline & & & Profit Mar & & \\
\hline & (1) & (2) & (3) & (4) & (5) \\
\hline CEI & $0.0124^{* * *}$ & $0.0190^{* * *}$ & $0.0152^{*}$ & $0.0130^{*}$ & -0.0051 \\
\hline & $(7.222)$ & $(2.814)$ & $(1.900)$ & $(1.887)$ & $(-0.397)$ \\
\hline $\log (\mathrm{BM})$ & $-1.4850^{* *}$ & $-1.5150^{* * *}$ & $-2.5790^{* * *}$ & $-1.5032^{* * *}$ & 0.4062 \\
\hline & $(-4.263)$ & $(-5.146)$ & $(-8.158)$ & $(-5.151)$ & $(0.492)$ \\
\hline $\log ($ Size $)$ & $1.5754^{* * *}$ & $1.5087^{* * *}$ & $2.0775^{* * *}$ & $1.5022^{* * *}$ & 0.1511 \\
\hline & $(31.04)$ & $(9.455)$ & $(10.19)$ & $(9.455)$ & $(0.239)$ \\
\hline Log(Age) & 0.5674 & $0.8005^{* * *}$ & 0.0447 & $0.7685^{* * *}$ & $7.1831^{* * * *}$ \\
\hline & $(2.093)$ & $(3.249)$ & $(0.181)$ & $(3.162)$ & $(4.127)$ \\
\hline Leverage & $-10.3703^{\text {*** }}$ & $-11.2197^{* * *}$ & 0.6773 & $-10.7625^{* * *}$ & $-26.3428^{* * *}$ \\
\hline & $(-14.32)$ & $(-9.769)$ & $(0.712)$ & $(-9.228)$ & $(-5.447)$ \\
\hline Fama-MacBeth & Yes & - & - & - & - \\
\hline Industry-fixed effects & Yes & Yes & - & Yes & - \\
\hline Year-fixed effects & - & - & Yes & Yes & - \\
\hline Firm-fixed effects & - & - & - & - & Yes \\
\hline $\mathrm{N}$ & 1283 & 1283 & 1283 & 1283 & 1283 \\
\hline $\operatorname{Adj} R^{2}$ & 0.482 & 0.479 & 0.288 & 0.483 & 0.728 \\
\hline
\end{tabular}


Table 8 Labor market evidence - Employee productivity and CEI index

This table presents the results of regressions of revenue per employee on the CEI, for a sample of 1,283 firm years from 2002 to 2006. The dependent variable is the logarithm of revenue divided by the number of employees. $\log (\mathrm{Age})$ is the logarithm of number of years available in CRSP. S\&P 500 is a dummy set to one if a firm is included in the S\&P 500 index, and zero otherwise. $\log (\mathrm{BM})$ is the logarithm of the ratio of book value of equity to the market value of equity. Herfindahl index is the sum of squared sales-based market shares of all firms in a 2-digit SIC industry in a given year, and its value lies between 0 and 1. Tangibility is the tangibility of the firm's assets, measured as the value of plant, property and equipment divided by total assets. $\log (\operatorname{Size})$ is the $\log$ of market capitalization, calculated as the natural logarithm of the market value of equity at the end of year $t$. Leverage is the total debt divided by the market value of total assets. $R \& D / S a l e s$ is $R \& D$ over sales where missing R\&D data are set to zero. For Fama-MacBeth regressions, industry-fixed effects are included and time-series average values of the annual regression coefficients are reported with time-series t-statistics calculated using Newey-West standard errors in parentheses. For other regressions, t-statistics calculated using standard errors corrected for heteroskedasticity are reported in parentheses. Constants are not reported. Industries are 48 industries classified by Fama-French (1997). ***,**, and * denote significance at the $1 \%, 5 \%$ and $10 \%$ levels.

\begin{tabular}{cccccc}
\hline & \multicolumn{5}{c}{$\log ($ Revenue/Employment) } \\
\cline { 2 - 6 } CEI & $(1)$ & $(2)$ & $(3)$ & $(4)$ & $(5){ }^{* * * *}$ \\
& $0.0019^{* * *}$ & $0.0024^{* * *}$ & 0.0005 & $0.0018^{* *}$ & $0.0019^{* * *}$ \\
Log(Age) & $(14.53)^{* *}$ & $(3.505)$ & $(0.476)$ & $(2.548)$ & $\left.(4.21)^{*}\right)$ \\
& $-0.0523^{* *}$ & -0.0439 & $0.0624^{* *}$ & $-0.0527^{*}$ & $0.2897^{* * *}$ \\
S\&P 500 & $(-3.662)$ & $(-1.555)$ & $(2.014)$ & $(-1.853)$ & $(4.540)$ \\
& $-0.0645^{*}$ & -0.0857 & -0.0458 & -0.0605 & - \\
Log(BM) & $(-2.468)$ & $(-1.605)$ & $(-0.667)$ & $(-1.128)$ & \\
& $0.0878^{* * *}$ & $0.0810^{* * *}$ & $0.3867^{* * *}$ & $0.0908^{* * *}$ & $-0.0533^{*}$ \\
Tangibility & $(17.59)^{* *}$ & $(2.942)$ & $(11.36)^{* *}$ & $(3.260)$ & $(-1.774)^{* * *}$ \\
& $-0.6060^{* * *}$ & $-0.6048^{* * *}$ & $-0.9924^{* *}$ & $-0.5868^{* * *}$ & $-1.1156^{* * *}$ \\
Log(Size) & $(-4.636)$ & $(-4.659)$ & $(-7.485)$ & $(-4.506)$ & $(-4.490)$ \\
& $0.0888^{* * *}$ & $0.0900^{* * *}$ & $0.1743^{* * *}$ & $0.0849^{* * *}$ & 0.0503 \\
R\&D/Sales & $(8.248)$ & $(7.123)$ & $(10.07)$ & $(6.700)$ & $(1.607)^{* * *}$ \\
& $0.6333^{* *}$ & 0.5038 & $0.5359^{* *}$ & 0.5588 & $-2.8971^{* *}$ \\
Fama-MacBeth & $(3.837)$ & $(0.991)$ & $(1.921)$ & $(1.100)$ & $(-4.310)$ \\
Industry-fixed effects & Yes & - & - & - & - \\
Year-fixed effects & Yes & Yes & - & Yes & - \\
Firm-fixed effects & - & - & Yes & Yes & - \\
N & - & - & - & - & Yes \\
Adj R ${ }^{2}$ & 1283 & 1283 & 1283 & 1283 & 1283 \\
& 0.599 & 0.638 & 0.220 & 0.642 & 0.971 \\
\hline
\end{tabular}


Table 9 Labor markets evidence - Employment and CEI index

This table presents the results of regressions of employment on the CEI for a sample of 1,283 firm years from 2002 to 2006 . The dependent variable is the logarithm of the number of employees. $\log (\mathrm{Age})$ is the logarithm of number of years available in CRSP. S\&P 500 is a dummy set to one if a firm is included in the S\&P 500 index, and zero otherwise. $\log (\mathrm{BM})$ is the logarithm of the ratio of book value of equity to the market value of equity. Herfindahl index is the sum of squared sales-based market shares of all firms in a 2-digit SIC industry in a given year, and its value lies between 0 and 1. Tangibility is the tangibility of the firm's assets, measured as the value of plant, property and equipment divided by total assets. $\log ($ Size $)$ is the logarithm of market capitalization, calculated as the natural logarithm of the market value of equity at the end of year $t . \mathrm{R} \& \mathrm{D} /$ Sales is $\mathrm{R} \& \mathrm{D}$ over sales, where missing R\&D data are set to zero. For Fama-MacBeth regressions, industry-fixed effects are included and time-series average values of the annual regression coefficients are reported with timeseries t-statistics calculated using Newey-West standard errors in parentheses. For other regressions, t-statistics calculated using standard errors corrected for heteroskedasticity are reported in parentheses. Constants are not reported. Industries are 48 industries classified by Fama-French (1997). ${ }^{* * *},{ }^{* *}$, and ${ }^{*}$ denote significance at the $1 \%, 5 \%$ and $10 \%$ levels.

\begin{tabular}{cccccc}
\hline & \multicolumn{5}{c}{$\log ($ Employment $)$} \\
\cline { 2 - 5 } CEI & $(1)$ & $(2)$ & $(3)$ & $(4)$ & $(5)$ \\
& $0.0012^{* *}$ & 0.0007 & 0.0006 & $0.0019^{* *}$ & 0.0007 \\
Log(Age) & $(4.553)$ & $(0.829)$ & $(0.440)$ & $(2.114)$ & $(1.577)$ \\
& 0.0420 & 0.0228 & 0.0120 & 0.0360 & $0.1902^{* * *}$ \\
S\&P 500 & $(1.698)$ & $(0.681)$ & $(0.269)$ & $(1.087)$ & $(3.190)$ \\
& 0.0107 & 0.0738 & -0.0825 & 0.0318 & \\
Log(BM) & $(0.332)$ & $(1.168)$ & $(-1.055)$ & $(0.501)^{* * *}$ & \\
& $0.3091^{* * *}$ & $0.3409^{* * *}$ & 0.0306 & $0.3223^{* *}$ & $0.1639^{* * *}$ \\
Tangibility & $(9.134)^{* *}$ & $(10.30)$ & $(0.763)$ & $(9.714)^{* * *}$ & $(4.400)^{* *}$ \\
& $0.9491^{* * *}$ & $0.8627^{* * *}$ & $1.2720^{* * *}$ & $0.8324^{* * *}$ & $0.8080^{* *}$ \\
Log(Size) & $(11.14)$ & $(4.782)$ & $(8.498)$ & $(4.650)$ & $(2.998)$ \\
& $0.6825^{* * *}$ & $0.6460^{* * *}$ & $0.5387^{* * *}$ & $0.6541^{* * *}$ & $0.1122^{* * *}$ \\
R\&D/Sales & $(38.07)$ & $(26.44)^{* * *}$ & $(12.55)$ & $(26.23)$ & $(2.693)$ \\
& $-7.0379^{* * *}$ & $-6.6445^{* * *}$ & $-4.3690^{* * *}$ & $-6.8034^{* * *}$ & 0.2335 \\
Fama-MacBeth & $(-41.51)$ & $(-10.60)$ & $(-9.811)$ & $(-11.02)$ & $(0.406)$ \\
Industry-fixed effects & Yes & - & - & - & - \\
Year-fixed effects & - & Yes & - & Yes & - \\
Firm-fixed effects & - & - & Yes & Yes & - \\
$\mathrm{N}$ & 1283 & 1283 & - & - & Yes \\
Adj R $\mathrm{R}^{2}$ & 0.716 & 0.725 & 0.412 & 0.731 & 1283 \\
\hline
\end{tabular}


Table $10 \mathrm{CEI}$ index and firm characteristics

This table summarizes the results of regressions of the CEI index on firm characteristics, for a sample of 1,283 firm years from 2002 to 2006. The dependent variable is the CEI index. $\log ($ Age) is the logarithm of the number of years available in CRSP. S\&P 500 is a dummy set to one if a firm is included in the S\&P 500 index, and zero otherwise. $\log (\mathrm{BM})$ is the logarithm of the ratio of book value of equity to the market value of equity. Herfindahl index is the sum of squared sales-based market shares of all firms in a 2-digit SIC industry in a given year, and its value lies between 0 and $1 . \log ($ Size $)$ is the logarithm of market capitalization, calculated as the natural logarithm of the market value of equity at the end of year $t$. $\mathrm{R} \& \mathrm{D} /$ Sales is $\mathrm{R} \& \mathrm{D}$ over sales, where missing $\mathrm{R} \& \mathrm{D}$ data are set to zero. Leverage is the total debt divided by the market value of total assets. For Fama-MacBeth regressions, industry-fixed effects are included and time-series average values of the annual regression coefficients are reported with time-series t-statistics calculated using Newey-West standard errors in parentheses. For other regressions, t-statistics calculated using standard errors corrected for heteroskedasticity are reported in parentheses. Constants are not reported. Industries are 48 industries classified by Fama-French (1997). ***,**, and * denote significance at the $1 \%, 5 \%$ and $10 \%$ levels.

\begin{tabular}{ccccccc}
\hline & \multicolumn{7}{c}{ CEI } \\
\cline { 2 - 7 } S\&P 500 & $(1)$ & $(2)$ & $(3)$ & $(4)$ & $(5)$ & $(6)$ \\
& 2.383 & 1.780 & $6.095^{* * *}$ & 2.847 & 1.133 & - \\
Log(Age) & $(0.824)$ & $(0.916)$ & $(3.594)$ & $(1.494)$ & $(0.574)$ & \\
& $-2.440^{* *}$ & $-1.817^{*}$ & $-3.634^{* * *}$ & $-2.815^{* * *}$ & -1.044 & $31.179^{* * *}$ \\
Log(Size) & $(-2.657)$ & $(-1.820)$ & $(-4.420)$ & $(-3.097)$ & $(-1.059)$ & $(6.446)$ \\
& $4.462^{* * *}$ & $4.568^{* * *}$ & $3.169^{* * *}$ & $3.895^{* * *}$ & $3.361^{* * *}$ & 0.552 \\
Log(BM) & $(25.88)$ & $(7.919)$ & $(5.976)$ & $(6.984)$ & $(5.929)$ & $(0.185)$ \\
& 1.022 & 0.293 & -0.471 & -0.603 & 0.001 & 2.300 \\
R\&D/Sales & $(1.226)$ & $(0.246)$ & $(-0.466)$ & $(-0.596)$ & $(0.001)$ & $(1.223)$ \\
& $61.479^{* * *}$ & $60.933^{* * *}$ & $80.971^{* * *}$ & $54.065^{* * *}$ & $71.485^{* * *}$ & 44.673 \\
Leverage & $(8.134)$ & $(3.215)$ & $(6.895)$ & $(4.076)$ & $(3.699)$ & $(0.968)$ \\
& $27.148^{* * *}$ & $23.472^{* * *}$ & $21.931^{* * *}$ & $17.247^{* * *}$ & $21.627^{* * *}$ & $-25.425^{* *}$ \\
Herfindal & $(16.60)$ & $(5.337)$ & $(7.222)$ & $(5.540)$ & $(4.889)$ & $(-2.032)$ \\
& - & - & 3.892 & 3.415 & - & - \\
Fama-MacBeth & & & $(0.627)$ & $(0.510)$ & & \\
Industry-fixed effects & Yes & - & - & - & - & - \\
Year-fixed effects & - & Yes & - & - & Yes & - \\
State-fixed effects & & - & Yes & - & Yes & - \\
Firm-fixed effects & - & - & - & Yes & Yes & - \\
N & 1283 & 1283 & 1283 & 1283 & 1283 & 1283 \\
Adj R & 0.174 & 0.209 & 0.170 & 0.202 & 0.358 & 0.735 \\
\hline
\end{tabular}

